\begin{tabular}{|ccc|}
\hline & ANNALES INSTITUTI SLAVICI \\
& UnIVERSITATIS DEBRECENIENSIS & \\
SLAVICA XLVII & 2018 & DEBRECEN \\
\hline
\end{tabular}

Ольга РОМАНОВА - Екатерина ХАУНИНА

\title{
ОСОБЕННОСТИ ТЕАТРАЛЬНОЙ ДЕЯТЕЛЬНОСТИ В ВЕНГРИИ: ЗАКОНОДАТЕЛЬНЫЕ И ФИНАНСОВЫЕ ОСНОВЫ
}

\section{The Features of Theatrical Life in Hungary: The Legal and Financial Basis}

The present study is concerned with the Hungarian theatre system. In the first part general questions connected with the existing model of theatrical activity are treated. This is followed by an analytical review of modern Hungarian cultural legislation, in which special attention is paid to the structure and content of Law XCIX / 2008 "On the support and rules of employment in organizations of performing arts". Then all the existing present-day models of direct and indirect financial support of theatrical organizations are considered. Since the Hungarian and Russian theatre systems have some similar characteristics, the final part is devoted to possible partial adoption of Hungarian experience with a view to developing the institutions for the additional funding of Russian theatres.

Keywords: Cultural policy, public support, financing culture, theatre activity, theatre network, corporate tax system

Театральная система Венгерской республики в настоящее время существует на стыке традиций и новых политико-экономических тенденций. С одной стороны, ощутимо влияние недавнего прошлого - управление страной Венгерской партией трудящихся (коммунистической партией) в течение сорока лет до 1990 г. Этому режиму были свойственны высокая доступность культурных благ для общества и отсутствие профессиональной конкуренции среди театров из-за большой субсидии. С другой стороны, начавшееся около 30 лет назад приближение к Европе: смена политической власти и переход к демократии, затем вступление в Европейский союз в 2004 г. Влияние политической сферы на культуру Венгрии - это особенная черта, которая ярко отражает специфику функционирования всех театральных учреждений в стране. Итогом изменений является крайне рассеянная информационная и статистическая база экономических показателей театральной сферы, что значительно усложняет ее анализ.

На основе собранных данных о театральной сфере можно провести следующие аналитические размышления и выводы. В стране существует большой массив стационарных театров с постоянной актерской труппой (335 сценических площадок в 2016 г.), которые успешно занимаются творческой деятельностью вопреки общей европейской тенденции работы театра-площадки для показа спектаклей разными коллективами. В Табл. 1 видно, как в послед- 
ние годы прогрессирует театральная система в целом и увеличиваются все количественные показатели. С 2000 г. количество театров увеличилось в 3,5 раза, и к 2016 г. в Венгрии количество театров на 1 млн. жителей составляло 18 , когда в России этот показатель достигал 4,5. Количество показов спектаклей, например, за 7 лет увеличилось в 1,5 раза при таком же увеличении количества посещений, что говорит о повышении спроса на показ спектаклей при общем падении уровня населения за этот же период - уменьшении примерно на 20000 человек ежегодно. Соответственно увеличился и доход от продажи билетов - практически в три раза.

Табл. 1. Общая информащия по театрам Венгрии 2010-2016 г2.

\begin{tabular}{|c|c|c|c|c|c|}
\hline Год & $\begin{array}{l}\text { Количество } \\
\text { театров }\end{array}$ & $\begin{array}{l}\text { Количество } \\
\text { показов } \\
\text { спектаклей }\end{array}$ & $\begin{array}{l}\text { Количе- } \\
\text { ство посе- } \\
\text { щений, } \\
\text { тыс. чел. }\end{array}$ & $\begin{array}{l}\text { Доход от } \\
\text { билетов в } \\
\text { текущих } \\
\text { ценах, тыс. } \\
\text { евро }\end{array}$ & $\begin{array}{l}\text { Средняя } \\
\text { стои- } \\
\text { мость } \\
1 \text { посе- } \\
\text { щения, } \\
\text { евро }\end{array}$ \\
\hline 2010 & 143 & 19188 & 4580 & 28327,1 & 6,2 \\
\hline 2011 & 170 & 21185 & 4735 & 29149,9 & 6,2 \\
\hline 2012 & 167 & 21677 & 5128 & 33475,4 & 6,5 \\
\hline 2013 & 164 & 23381 & 5824 & 58243,7 & 10,0 \\
\hline 2014 & 168 & 25625 & 6462 & 58068,2 & 9,0 \\
\hline 2015 & 170 & 26473 & 6736 & 69167,1 & 10,3 \\
\hline 2016 & 179 & 28660 & 7146 & 79127,4 & 11,1 \\
\hline
\end{tabular}

Источник: A színpadi szórakoztatás, 2016; KÖZPONTI STATISZTIKAI HIVATAL, 2017 Опубликовано: 14.12.2017 Режим доступа: http://www.ksh.hu/, свободный.Загл.сэкрана. Яз. венгерский (дата обращения: 24.12.2017).

Также есть возможность проанализировать и ценовую политику: среднюю сумму, которая потребуется потребителю для покупки одного билета. Средняя заработная плата в Венгрии в 2016 г. составила 570 евро, то есть среднестатистическому жителю нужно будет потратить $2 \%$ от заработной платы на билет.

В Венгрии, как и в России, осталось множество площадок, построенных до 1990 г. на большое количество зрителей (700-1000 человек), но нередко основная сцена рассчитана на 150-400 зрителей, и если в среднем на один спектакль приходит 249 чел. (этот показатель включает показы на малых сценах - 
вместительностью примерно до 100 человек в среднем), то это свидетельствует об очень высокой посещаемости.

\section{Законодательная система Венгрии}

Сегодня культурная деятельность Венгрии, а особенно театральная система, представляет собой работу уникальных в своем роде организаций, существующих в различных юридических формах. Венгерский театр, в частности, сохранил разнообразие форм, и в настоящее время творческая инициатива может воплотиться в отдельном проекте - современный европейский принцип работы, присущий большинству компаний Европейской экономической зоны, а может с течением времени из ежегодного проекта перерасти в постоянно работающую организацию. Несмотря на очевидную тенденцию сокращения количества стационарных театров в Европе, Венгрия сохранила основной театральный массив и сценические традиции. Произошло это во многом благодаря культурной политике страны и ее законодательной системе.

Согласно конституции, администрацией культуры высшего уровня в Венгрии является государственный секретариат в Министерстве человеческих ресурсов. Главным ответственным лицом в Комитете по культуре и печати является государственный секретарь по культуре. Иными словами, сфера культуры в Венгрии на данный момент не управляется самостоятельным государственным органом, а входит в группу направлений работы Министерства человеческих ресурсов наряду с образованием, спортом, медициной и транспортом. При этом управление некоторыми областями культуры осуществляется другими органами правительства: учреждениями за границей руководит министр внешних экономических связей, большая часть финансирования киноиндустрии распределяется министром экономического развития, а архитектурное и археологическое наследие находится в ведении канцелярии премьер-министра и региональных правительств. То есть, ответственность за сектор культуры несет множество правительственных органов и организаций, поэтому межминистерское или межправительственное сотрудничество в вопросах культуры является обязательным для правильного функционирования системы.

Еще с 1990 г. Венгерская законодательная система определила деятельность и статус некоммерческих организаций. В так называемом Некоммерческом Законе CLVI 1997 г. [перевод Act 1997 - CLVI on Public Benefit Organizations прим. авторов] определяются условия работы организаций и фондов «третьего» сектора. ${ }^{1}$ Он включает налоговые льготы для содействия и поддержки общественных целей. Ассоциации, фонды, а также некоммерческие предприятия могут, придерживаясь конкретных условий, квалифицироваться как общественнополезные организации. Некоторые театры в настоящее время зарегистрированы в форме фонда, ассоциации, или имеют отдельный фонд по сбору средств

1 Act 1997 - CLVI on Public Benefit Organizations / [Электронный pecypc]: Hungarian PBO Act. Режим доступа: http://www.c3.hu/ civital/NPTV.html, свободный.Загл.сэкрана. Яз. англ. (дата обращения: 30.11 .17 ) 
для творческой деятельности, поэтому данный вид регулирования также благоприятен для организации театрального дела.

Венгерское государство уделяет большое внимание налоговому законодательству, что благоприятно влияет на инвестиции в сфере искусства. В этом отношении выделяется Закон II / 2004 об авторских картинах или Закон о кино, предлагающий налоговый вычет в размере $25 \%$ для спонсоров и создателей кинопроектов. Данная льгота привлекла международные кинокомпании, а также простимулировала отечественное кинопроизводство. Этот закон также создал благоприятные условия инвестирования киностудий, крупнейшей из которых является Студия Александра Корда. Благополучный опыт введения данного закона привел к разработкам налоговой поддержки в сфере исполнительских искусств.

После нескольких успешных шагов в области культурного законодательства в 2008 г. Венгрия совершила сильный прорыв - появился Закон $\mathrm{XCIX/2008} \mathrm{«О} \mathrm{поддержке} \mathrm{и} \mathrm{правилах} \mathrm{трудовой} \mathrm{занятости} \mathrm{в} \mathrm{организациях} \mathrm{ис-}$ полнительского искусства». Его роль для культурной деятельности в Венгрии сложно переоценить. Он определяет типологизацию организаций исполнительских искусств (ОИИ), регулирует прямое бюджетное финансирование, систему налоговых льгот, работу государственных органов, а также самих творческих деятелей. Закон XCIX/2008 претерпел множество изменений, и поправки в него вносятся ежегодно, в данной работе используется вариант с последними поправками, вступившими в силу в июле 2017 года. ${ }^{2}$ Ниже приведена общая структура закона (Рис. 1).

2 Beiktatta: 2017. évi LXVIII. törvény 5. § (2). Hatályos: 2017. VII. 1-től / 2008. évi XCIX. törvény az előadó-mủvészeti szervezetek támogatásáról és sajátos foglalkoztatási szabályairól [Электронный ресурс]. Режим доступа:

https://net.jogtar.hu/jogszabaly?docid=a0800099.tv, свободный. Загл. с экрана. Яз. Венгерский (дата обращения: 11.01.18) 


\begin{tabular}{|c|c|}
\hline I глава & $\begin{array}{l}\cdot \text { •Цели } \\
\text { •Задачи } \\
\text { •Принципы }\end{array}$ \\
\hline лава & $\begin{array}{l}\text { •Определение субъектов (государственные органы и } \\
\text { ОИИ) } \\
\text { •Их права и обязанности }\end{array}$ \\
\hline & $\begin{array}{l}\text { •Государственный регистр } \\
\text { •Категоризация ОИИ } \\
\text { •Договор о государственной службе }\end{array}$ \\
\hline глава & •Система государственной поддержки \\
\hline глава & •Права и обязанности творческих работников ОИИ \\
\hline глава & • Заключительные положения (глоссарий и проч.) \\
\hline
\end{tabular}

Рис. 1. Структура Закона XCIX/2008 «О поддержке и правилах трудовой занятости в организациях исполнительского искусства»

Источник: 2008. évi XCIX. törvény az elöadó-múvészeti szervezetek támogatásáról és sajátos foglalkoztatási szabályairól [Электронный pecypc]. Peжим доступа: https://net.jogtar.hu/jogszabaly?docid=a0800099.tv, свободный. Загл. с экрана. Яз. венгерский (дата обращения: 11.01.18).

Из первой главы этого закона можно понять цели и задачи, которые закладывало в него государство:

«...Любая живая, современная художественная работа - это социальная деятельность, которая не может быть заменена ничем, которая воспитывает и развивает культурное и интеллектуальное состояние общества, культуру родного языка, социальное самосознание и солидарность, а также способствует продол- 
жению европейской, и особенно венгерской культурной истории. Цель этого закона - поддерживать работу и развитие качественного исполнительского искусства, театра, танца и музыки в Венгрии...» [перевод Романовой О.А. ${ }^{3}$ ].

Основными задачами введения этого закона были определены развитие венгерского национального исполнительского искусства, повышение его доступности для зрителя, культурное воспитание общества, поддержка присутствия венгерского искусства на международной арене, сокращение региональных различий в доступе к культурным благам, а также оптимизация расходования государственных средств.

В законе предлагается целая система субъектов-участников (Табл. 2): государство, организация исполнительских искусств, ее представители и работники.

Табл. 2. Субъекты Закона ХСІХ/2008

\begin{tabular}{|c|c|c|c|}
\hline \multirow[t]{2}{*}{ Субъект } & \multicolumn{2}{|c|}{ Административная структура } & \multirow{2}{*}{$\begin{array}{l}\text { Функции согласно За- } \\
\text { кону ХCIX/2008 }\end{array}$} \\
\hline & \begin{tabular}{l}
\multicolumn{1}{c}{ Ори- } \\
гинальное \\
название
\end{tabular} & Перевод автора & \\
\hline \multirow[t]{2}{*}{ Государство } & $\begin{array}{l}\text { A kultúrá- } \\
\text { ért felelős } \\
\text { miniszter }\end{array}$ & $\begin{array}{l}\text { Министр, ответствен- } \\
\text { ный за культуру }\end{array}$ & $\begin{array}{l}\text { 1. Регулирует деятельность } \\
\text { ОИИ в рамках Закона ХСІХ, } \\
\text { бюджетное финансирование } \\
\text { ОИИ } \\
\text { 2. Выполняет учредитель- } \\
\text { ную и надзорную функции } \\
\text { 3. Заключает с ОИИ дого- } \\
\text { вора о гос. службе на срок } \\
\text { от } 3 \text { лет } \\
\text { 4. Устанавливает критерии } \\
\text { для ОИИ категории «нацио- } \\
\text { нальные» и «с особым стату- } \\
\text { сом» } \\
\text { 5. Управляет Национальным } \\
\text { советом творческих деяте- } \\
\text { лей, комитетами искусств }\end{array}$ \\
\hline & $\begin{array}{l}\text { A Nemzeti } \\
\text { Előadó- } \\
\text { müvészeti } \\
\text { Érdek- } \\
\text { egyeztető } \\
\text { Tanács } \\
\text { (NEÉT) }\end{array}$ & $\begin{array}{l}\text { Национальный совет } \\
\text { творческих деятелей }\end{array}$ & $\begin{array}{l}\text { 1. Осуществляет встречи (не } \\
\text { реже } 1 \text { раза в год) по созыву } \\
\text { министра. На встречах об- } \\
\text { суждается деятельность ко- } \\
\text { митетов искусств (выраже- } \\
\text { ние экспертного мнения) }\end{array}$ \\
\hline
\end{tabular}

3 2008. évi XCIX. törvény az előadó-művészeti szervezetek támogatásáról és sajátos foglalkoztatási szabályairól [Электронный ресурс]. Режим доступа:

https://net.jogtar.hu/jogszabaly?docid=a0800099.tv, свободный. Загл. с экрана. Яз. Венгерский (дата обращения: 11.01.18) 


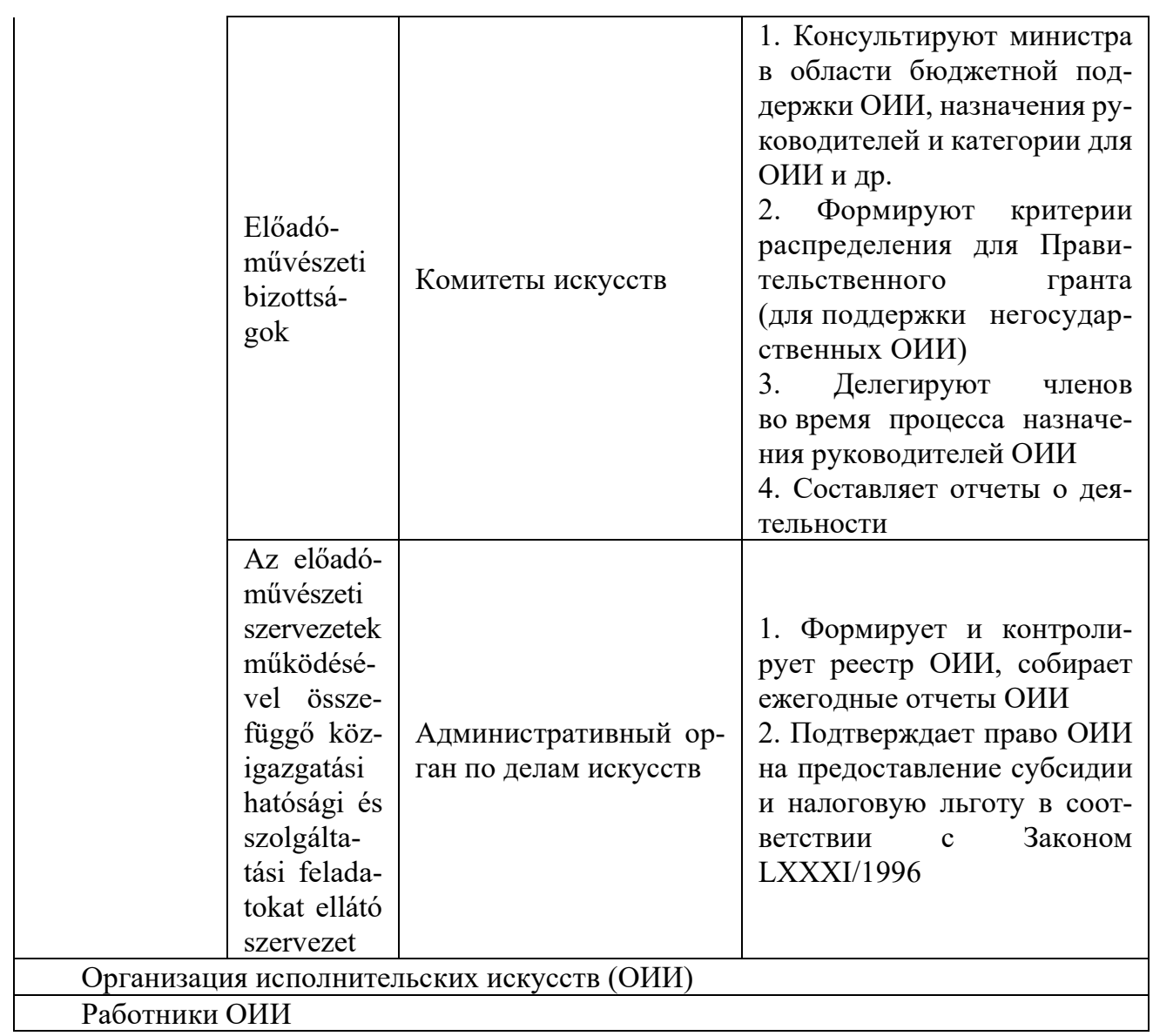

Источник: 2008. évi XCIX. törvény az előadó-művészeti szervezetek támogatásáról és sajátos foglalkoztatási szabályairól [Электронный pecypc]. Режим доступа: https://net.jogtar.hu/jogszabaly?docid=a0800099.tv, свободный. Загл. с экрана. Яз. венгерский (дата обращения: 11.01.18).

Со стороны субъекта «Государство» в регулировании и контроле действий организаций исполнительского искусства принимают участие несколько органов. Во-первых, министр, ответственный за культуру. Он несет ответственность за законодательное регулирование деятельности организаций исполнительских искусств, за оформление государственного контракта о работе сроком от трех лет ${ }^{4}$.

Во-вторых, Национальный совет творческих деятелей, который состоит из 24 членов и переизбирается каждые 4 года (с возможным продлением

4 Договор о государственной службе - договор государства или местных властей с ОИИ о предоставлении творческих услуг на срок не менее трех лет с указанием количества необходимых выступлений или концертов, срока и места предоставления услуг и вознаграждения за выполнение. 
срока). Члены совета осуществляют деятельность на безвозмездной основе. В состав совета входят директора театров, драматурги, актеры, преподаватели творческих ВУЗов, представители профсоюзов и независимых организаций. ${ }^{5}$ На встречах, созываемых министром, совет обсуждает деятельность и решения комитетов искусств.

В-третьих, согласно Закону XCIX/2008 министр создает три комитета искусств: Комитет театрального искусства (не менее 5 членов), Танцевальный и Музыкальный комитеты (не менее 3 членов в каждом). В состав комитетов входят уважаемые творческие деятели: директора театров, хореографы, музыканты, дирижеры, профессоры в области музыкального искусства. ${ }^{6}$ Министр приглашает творческих деятелей в комитеты бессрочно и за отдельную надбавку к окладу.

В-четвертых, для получения финансовой поддержки в рамках системы налоговых льгот организации исполнительских искусств взаимодействуют с Административным органом по делам искусств, созданным по Постановлению Правительства. Он ведет специальный реестр ${ }^{7}$, в котором обязаны зарегистрироваться все организации исполнительского искусства для получения Сертификата поддержки, который в дальнейшем понадобится им для обращения в корпорации. На момент 2018 г. 448 организаций зарегистрировано в данном реестре. В нем указываются следующие данные:

- наименование и форма организации,

- юридический и фактический адрес,

- учредитель или представитель организации,

- количество мест для зрителей,

- принадлежащие здания,

- регистрационный номер,

- направление художественной деятельности (театр, музыкальный, хоровой, танцевальный или балетный ансамбль),

- тип деятельности (театр кукол, симфонический оркестр и проч.),

- другая информация.

В рамках процесса регистрации есть несколько примечаний. Например, негосударственная организация может быть зарегистрирована только после трех

5 Nemzeti Előadó-művészeti Érdekegyeztető Tanács (NEÉT) / AZ EMBERI ERŐFORRÁSOK MINISZTÉRIUMA ÜGYFÉLSZOLGÁLATI PORTÁLJA [Электронный ресурс] Опубликовано: - Режим доступа:

http://emmiugyfelszolgalat.gov.hu/eloado-muveszeti-osztaly/neet/nemzeti-eloado-muveszeti, свободный.Загл.сэкрана. Яз. венгерский (дата обращения: 10.03.17)

6 Előadó-művészeti bizottságok / AZ EMBERI ERÖFORRÁSOK MINISZTÉRIUMA ÜGYFÉLSZOLGÁLATI PORTÁLJA [Электронный ресурс] Опубликовано: - Режим доступа: http://emmiugyfelszolgalat.gov.hu/eloado-muveszeti-osztaly/eloado-muveszetibizottsagok/eloado-muveszeti

свободный.Загл.сэкрана.Яз. венгерский (дата обращения: 10.03.17)

7 Государственная база данных, которую ведет государственный орган по делам искусств (см. п. 2.2.), и которая содержит данные о бюджетных ОИИ, общественно-полезных и других профессиональных ОИИ. Данные реестра с 2012 года являются общедоступными и публикуются на интернет-сайтах ОИИ. 
лет деятельности. В реестр также попадают социальные организации, защищающие интересы исполнительского искусства (фонды, ассоциации и прочее). При отсутствии государственной поддержки в течении пяти лет подряд зарегистрированная организация удаляется из реестра.

Немаловажную роль в нынешнем облике венгерской культуры сыграли стратегические документы последних лет. К ним можно отнести составленные в 2012 г. среднесрочные стратегии, которые были опубликованы девятью комитетами Национального культурного фонда - независимой организации по целевому финансированию. Также под контролем премьер-министра и Европейского союза была создана Программа по развитию человеческих ресурсов Венгерской республики до 2020 г. (Emberi Erőforrás Fejlesztési Operatív Program), связанная с культурными направлениями. В настоящее время на стратегическое планирование в культуре влияет и региональная политика ЕС 2014-2020 гг.

Результаты работы законодательных и исполнительных органов власти в Венгрии можно также оценить и через богатую систему финансовой поддержки культурной деятельности, о которой речь пойдет далее.

\section{Многоканальная система финансовой поддержки театральной дея- тельности в Венгрии}

Финансирование культуры в Венгрии разнообразно: существует несколько законодательно оформленных каналов поддержки с целью наиболее справедливого распределения денежных средств, направляемых в театры.

Особый статус театральных организаций определяется значительной поддержкой со стороны венгерского государства - в большинстве случаев собственные средства не составляют половины общего дохода. $42 \%$ - среднее значение для театров по статистическим данным за 2016 г. Доля субсидирования театрального дела относительно общего финансирования культуры в 2015 г. составляла $16 \%$ - 179,2 млн. евро 9 (всего 1,12 млрд. евро на сферу культуры). На Рис. 2 изменение распределения финансирования для трех смежных сфер искусства изображено в динамике с 2001 г. Значительные изменения в графике происходят в 2010 г., когда заметно снижение государственной поддержки культуры в отдельных отраслях: для венгерских театров, например, 2010 г. оказался столь же благоприятным, как неудачными для музыкальных и танцевальных компаний. За 15 лет соотношение выделения средств поменялось: театры вышли на лидирующую позицию, а направление танца стало отставать еще больше. В целом выделение финансирования увеличилось примерно в 2-3 раза, но нужно понимать, что динамика отображена в текущих ценах без учета инфляции, которая имела значительный диапазон за указанный период (от $-1,4 \%$ до $11 \%$ ).

8 Данные внутренней отчетности Венгерской республики 2009-2015 гг. [Электронный ресурс] Получено от Венгерского общества театров. Февраль 2017 г.

9 Magyar Statisztikai Évkönyv, 2016; Központi Statisztikai Hivatal, 2015 [Электронный ресурс] Опубликовано: 2016 г. Режим доступа: http://www.ksh.hu/, свободный. Загл. с экрана. Яз. венгерский (дата обращения: 15.03.2017) 


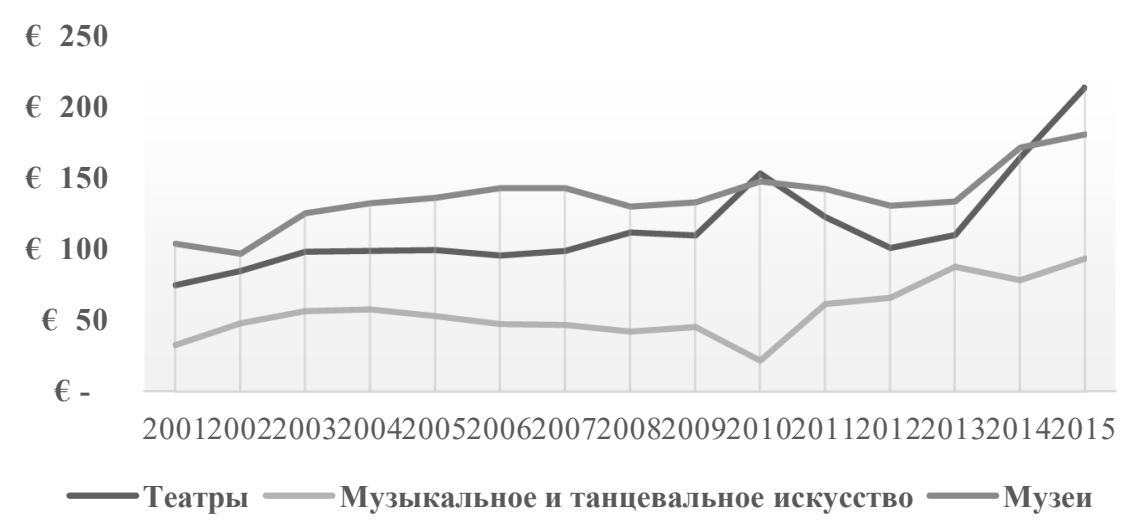

Рис. 2. Динамика бюджетного финансирования по направлениям культурной деятельности Венгрии в текущих ценах, в период 2001 - 2015 гг., млн. евро

Источник: Magyar Statisztikai Évkönyv, 2016; Központi Statisztikai Hivatal, 2015 [Электронный pecypc] Опубликовано: 2016 г. Режим доступа: http://www.ksh.hu/, свободный. Загл. с экрана. Яз. венгерский (дата обращения: 22.03.2017)

Субсидия центрального бюджета может быть распределена на следующие производственные и операционные расходы ${ }^{10}$ :

расходы, связанные с непосредственной художественной деятельностью; расходы на приобретение сценического оборудования и материалов;

привлечение творческих деятелей или творческой работы в рамках подготовки или проведения представления.

В том числе могут выделяться операционные гранты (поддержка от учредителя) на покрытие трат административно-хозяйственного управления и расходов в смежных сферах.

Театр ежегодно обязан направлять отчет по использованию бюджетных средств министру и одному из комитетов искусств. Отчет требуется присылать до 30 июня календарного года, следующего за отчетным, а также с 2012 года публиковать его на своем веб-сайте для публичного доступа.

Помимо прямого субсидирования, о котором также есть упоминание в Законе XCIX/2008, театры в Венгрии получают косвенную поддержку от налоговых перечислений, которая называется система $\boldsymbol{T A O}$. Это термин, применяемый театральными деятелями Венгрии в отношении процессуальной системы косвенной

10 Act XCIX of 2008 on the support and special employment rules of performing arts organisations [Электронный ресурс] Опубликовано: 08.12.2008 - Режим доступа: http://www.nefmi.gov.hu/letolt/english/act_xcix_2008_090624.pdf свободный.Загл. ээрана.Яз.англ. (дата обращения: 14.06.17) 
поддержки со стороны государства через налоговые льготы, которая активно используется в сфере исполнительского искусства (Закон XCIX/2008); далее по тексту - корпоративная налоговая система ТАО, система ТАO. ${ }^{11}$

Целью системы стало развитие деятельности музыкальных и танцевальных коллективов, оперы, театральных и цирковых организаций, в особенности камерных и малоизвестных. Также одним из целевых основных направлений этой системы была поддержка частной инициативы в области исполнительского искусства и отдельно муниципальных театров в городах с невысоким уровнем выделяемых субсидий в рамках регионального бюджета.

Упоминание о новом способе привлечения средств для некоммерческих организаций присутствует в 6(c) статье закона (также есть ссылки на дополнения в Законе LXXXI/1996 «О корпоративных и дивидендных налогах»).

Итак, после регистрации в специальном реестре, который ведет Административный орган по делам искусств, ОИИ получает Сертификат поддержки. В нем прописывается денежная сумма не более $80 \%$ сбора от проданных билетов и, вместе с тем, 1,5 миллиарда форинтов (по курсу на апрель 2018 г. примерно 4,8 млн. евро). Затем между корпорацией (налогоплательщиком) и организацией исполнительских искусств добровольно заключается договор об оказании поддержки на срок до восьми календарных лет. Согласно договору денежные средства поступают в ОИИ напрямую от налогоплательщика, который позднее получает данные средства обратно от Налоговой службы в виде вычета ${ }^{12}$.

На основании разобранного закона ниже схематично представлена современная корпоративная налоговая система ТАО (Рис. 3).

11 ТАО - аббревиатура на венгерском языке, обозначающая фразу «корпоративный налог» (társasági adó)

12 Налоговый вычет из корпоративного налога $-9 \%$. 

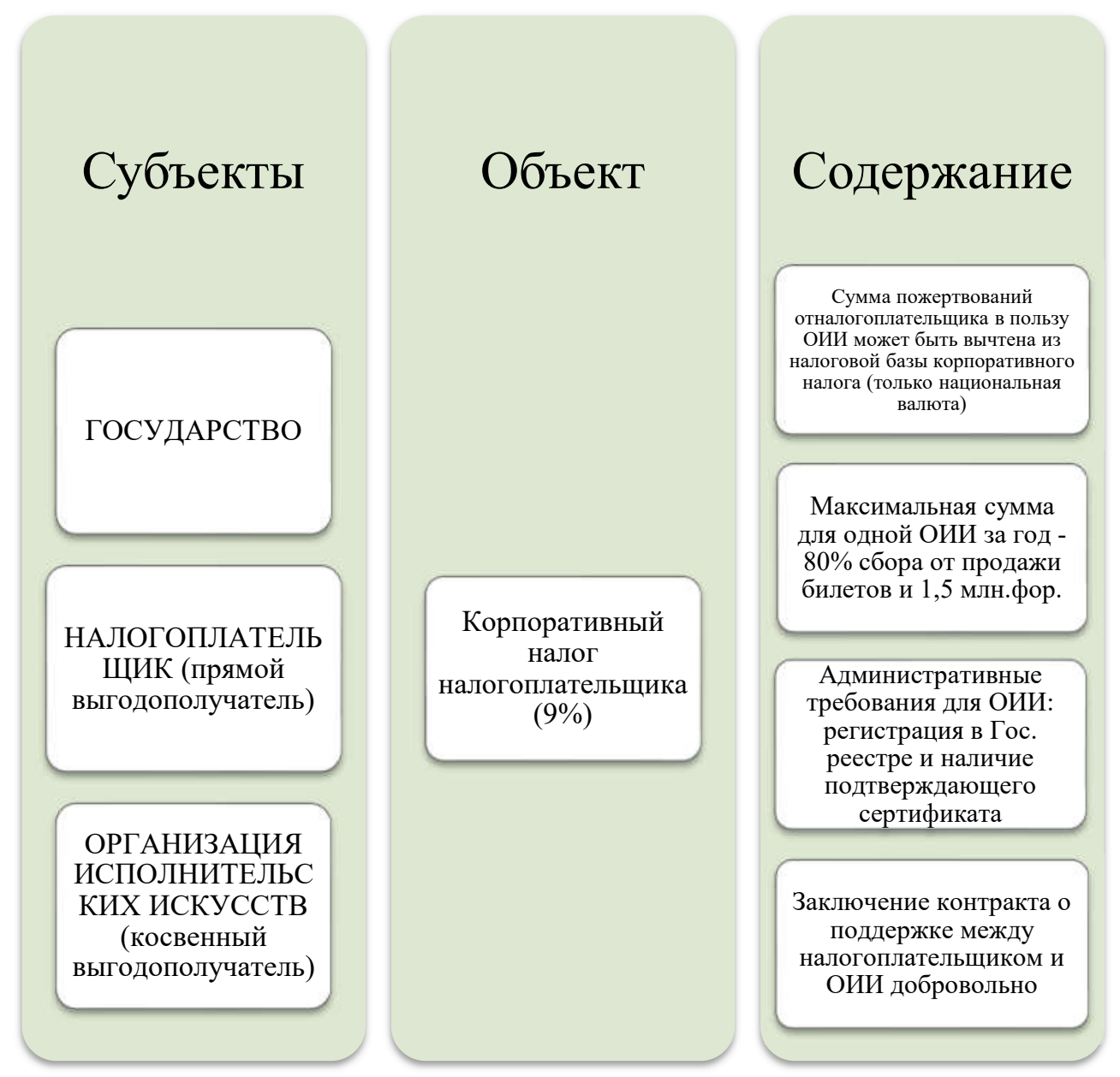

Рис. 3. Корпоративная налоговая система ТАО

Источник: 2008. évi XCIX. törvény az előadó-müvészeti szervezetek támogatásáról és sajátos foglalkoztatási szabályairól [Электронный pecypc]. Peжим доступа: https://net.jogtar.hu/jogszabaly?docid=a0800099.tv, свободный. Загл. с экрана. Яз. венгерский (дата обращения: 11.01.18); 1996. évi LXXXI. Törvény a társasági adóról és az osztalékadóról [Электронный pecypc]: Törvények és OGY határozatok. Опубликовано: 19.08.1996. Режим доступа: https://net.jogtar.hu/jogszabaly?docid=99600081.TV, свободный.Загл.сэкрана. Яз. венгерский (дата обращения: 18.06.17) 
Но помимо неоспоримой выгоды появления дополнительного источника финансирования существует целый ряд сложностей, с которыми столкнулись театральные деятели на практике:

Снижение прямого бюджетного субсидирования;

Расширение списка организаций - получателей вычетов (2013 г.);

Низкий уровень мотивации у корпораций из-за низкого налога;

Бюрократизация системы;

Коррупционные механизмы:

- посредники с дополнительной комиссией,

- фиктивные документы о проведении представлений;

6. Другие факторы: углубление политического кризиса, уменьшение ставки налога на коммунальные платежи и проч.

Система ТАО требует от организаций большой самостоятельности в привлечении новых компаний для сотрудничества. Театрам необходимо развивать маркетинговые стратегии, существовать в конкурентной среде с другими театрами и организациями исполнительского искусства. В настоящее время венгерские деятели театра уже хорошо освоили данную систему и обнаружили ряд недостатков, которые негативно влияют на общее функционирование театральной среды. Тем не менее, система определенно представляет большой интерес как оригинальный способ предоставления помощи от государства.

Финансирование театральной системы Венгрии не исчерпывается прямым субсидированием и системой ТАО, существует еще несколько законодательно оформленных каналов поддержки.

В начале 1990-х годов важным шагом для культуры страны, начинающей свой путь к демократии, стало создание учреждения по финансированию культурных проектов - Национального культурного фонда (НКФ), работа которого основана на управлении по принципу «вытянутой руки». НКФ создан для распределения государственных и негосударственных средств в формате грантов на основании проведения открытых конкурсов.

1 апреля 1993 г. был издан Закон XXIII/1993 «О создании Национального культурного фонда» ${ }^{13}$, в рамках которого была создана новая организация под управлением Министерства человеческих ресурсов с целью поддержки новых творческих инициатив, сохранения отечественной культуры, развития международных культурных отношений. В Национальном банке был открыт счет, на который поступали следующие средства: государственная помощь, добровольные взносы юридических и физических лиц, доходы от размещения временно свободных средств на банковских счетах (проценты по депозитам), доходы от приватизации государственных активов.

13 1993. évi XXIII. Törvény a Nemzeti Kulturális Alapról [Электронный pecypc] Törvények és OGY határozatok. Опубликовано: 31.03.1993. Режим доступа:

https://mkogy.jogtar.hu/?page=show\&docid=99300023.TV

свободный.Загл. сэкрана. Яз. венгерский (дата обращения: 17.06.17). 
Фонд финансирует проекты (только 5\% ресурсов может быть потрачено на оперативные и накладные расходы), созданные физическими лицами, юридическими лицами и бизнес-компаниями, зарегистрированным в Венгрии.

Каждая организация может подать заявку на грант и после победы в открытом тендере может заключить с фондом договор о предоставлении средств на определенные цели. Работу по приему и обработке заявок ведут 17 постоянно работающих коллегий, и одна из них - Коллегия театрального искусства - paботает с грантами театрального направления. Спектр направлений работы НКФ очень широк: от коллегии народного творчества и фотографии до строительства и туризма (Рис. 4).
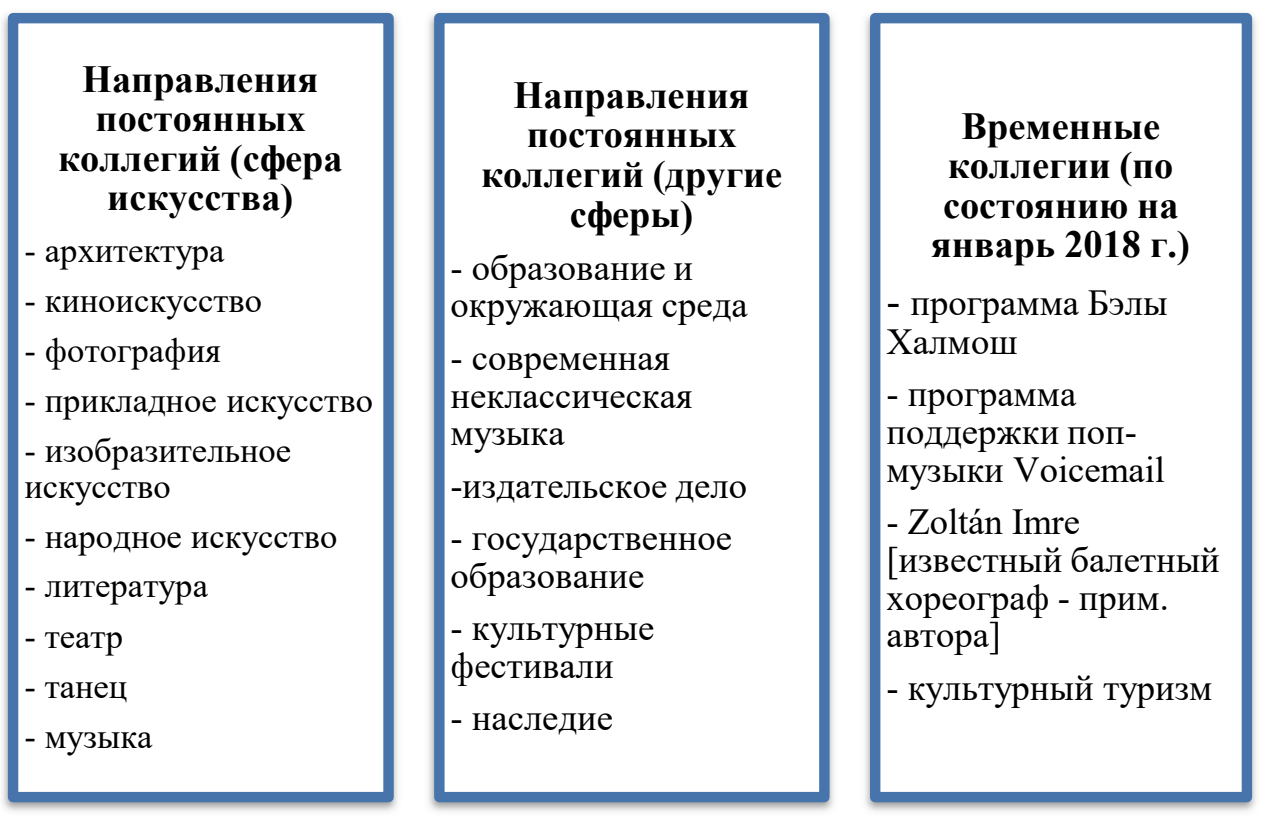

Рис. 4. Коллегии Национального культурного фонда (Последнее обновление: 20.12.2017 г.)

Источник: Nemzeti Kulturális Alap [Электронный ресурс] - Опубликовано: 20.12.2017 - Режим доступа: http://www.nka.hu/rolunk/nka, свободный. Загл. с экрана. Яз. венгерский (дата обращения: 12.01.18)

Национальный культурный фонд обладает значительным объемом средств в распоряжении: 11,7 млрд. форинтов в 2010 г.; 12,5 млрд. - в 2011 г.; 13,6 млрд. - в 2012 г.

С 1 января 2012 г. НКФ начал публиковать все данные о заявителях на гранты, о денежной сумме поддержки для победивших в тендере на своем официальном сайте, что сделало его работу более прозрачной. В 2013 г. было обработано 11283 заявки, а 11,7 млрд. форинтов было распределено между 7 276 грантополучателями, в среднем 1,04 млн. форинтов (около 3400 евро). 
Следующим механизмом для рассмотрения является институт индивидуальных назначений. Еще в 1996 г. в Венгрии был принят Закон CXXVI/1996 (2006), позволяющий культурным организациям получить дополнительную финансовую помощь - так называемая система «процентной филантропии». ${ }^{14}$ С 1996 г. средства в театральные организации и другие некоммерческие организации (НКО) могут направлять физические лица. Каждый работающий гражданин может распорядиться $1 \%$ от подоходного налога (уплаченного в прошлом налоговом периоде) в пользу неправительственной организации по своему выбору, а также $1 \%$ - перечислить для церкви (максимальное значение ставки индивидуального подоходного налога составляет 40\%). Для такого направления средств в налоговой службе каждому гражданину предлагается ввести специальный налоговый идентификационный номер организации в годовую декларацию о доходах, которой он хочет направить часть своих налогов.

Процедура проводится открыто с 2015 г.: налогоплательщики указывают в своих заявлениях свои имена, почтовые или электронные адреса для гражданского общества-бенефициара организации, после чего средства переводятся в НКО, которая, в свою очередь, до 31 октября того же года предоставляет отчет об использовании полученных средств. Данное нововведение помогло сделать процедуру перечисления $1 \%$ так называемой «традиционной филантропией». Также стали появляться специальные фонды для таких отчислений, внутри которых средства уже перераспределяются в виде тендеров в культурные организации.

Необходимо отметить, что появление данного механизма потребовало значительных затрат для государства: 1,2 млн. евро ( $0,5 \%$ всех затрат Налоговой администрации за год) было потрачено на почтовые расходы (50\%), банковские операции по переводу денежных средств (20\%) и другое (30\%) [ХАУнинА 2013: 170].

Более того, усилия государства оправдались не сразу. Хотя еще с момента введения этой системы многие организации стали активно информировать жителей о своей деятельности и идентификационном номере, только $35 \%$ налогоплательщиков воспользовались возможностью распределения $1 \%$ налога. К 2009 г. уже 50\% жителей вводили идентификационные номера НКО (помощь получили 30701 организация). В настоящее время номер легко узнать в сети Интернет, также его активно рекламируют в СМИ и с помощью уличной рекламы (например, баннерной рекламы на автобусных остановках). В 2012 г. согласно данным, предоставленными в открытый доступ налоговыми органами, 49\% налогоплательщиков направили 13,1 млрд. форинтов в 31101 организацию. Полный список получателей доступен на веб-сайте налогового органа. Например, Фонд камерного хора Бартока в городе Сольноке получил 159 000 форинтов (около 530 евро) от 39 анонимных доноров в 2012 г.

14 Act CXXVI of 1996 On the Use of a Specified Amount of Personal Income Tax in Accordance with the Taxpayer's Instruction. [Электронный pecypc]: International Center for Not-forProfit Law (ICNL). Режим доступа:

http://www.icnl.org/research/library/files/Hungary/portion_ENG.pdf, свободный.Загл. сэкрана. Яз. англ. (дата обращения: 12.01.2018); 
Частные пожертвования - наиболее слабо развитый институт по сравнению со всеми предыдущими. Связано это с большим количеством альтернативных вариантов помощи. В теории предприятия, компании и индивидуальные предприниматели могут вычесть $20 \%$ от стоимости пожертвований, предоставляемых НКО из их налоговой базы, а в случае многолетних объявленных взносов этот показатель составляет $40 \%$. Но несмотря на эти правила, филантропическая поддержка культурных организаций не особенно широко распространена и едва ли признана.

Существует следующее экспертное мнение: модель «процентной филантропии» как раз является промежуточной ступенью к развитой частной благотворительности [ХАУнИНА 2013: 174]. Результаты одного из венгерских исследований 2016 г. показали, что «процентная филантропия» благотворно влияет на частные пожертвования и волонтерскую деятельность. Для привлечения волонтеров в проекты культурной сферы нет конкретных положений в законодательстве - Закон LXXXVIII / 2005 обеспечивает необходимую правовую среду и защиту для общественной добровольной работы. Социальная и экономическая ситуация Венгрии пока что не позволяют создать благоприятную почву для данных институтов.

Казалось бы, более перспективной формой сотрудничества коммерческого сектора и НКО будет спонсорство, но и здесь нет глобальной инициативы. Есть ряд частных примеров, которые служат больше исключением, чем правилом. Например, театр в Будапеште Katona József Színház имеет опыт многолетнего сотрудничества с компанией MasterCard. По тендеру, который проходит раз в четыре года, MasterCard выделил театру солидные средства на реконструкцию здания (100.000 евро). В обмен компания получила следующее преимущество: внутри театра есть бар, который работает по договору аренды с театром (одна и та же компания обслуживает 3 бара: 2 зрительских и 1 служебный) - в дневное время все посетители могут расплатиться в баре только безналичным расчетом.

В качестве иллюстрации ниже представлен рисунок (Рис. 5), включающий все институты поддержки театрального искусства в Венгрии, рассмотренные в данной работе. 


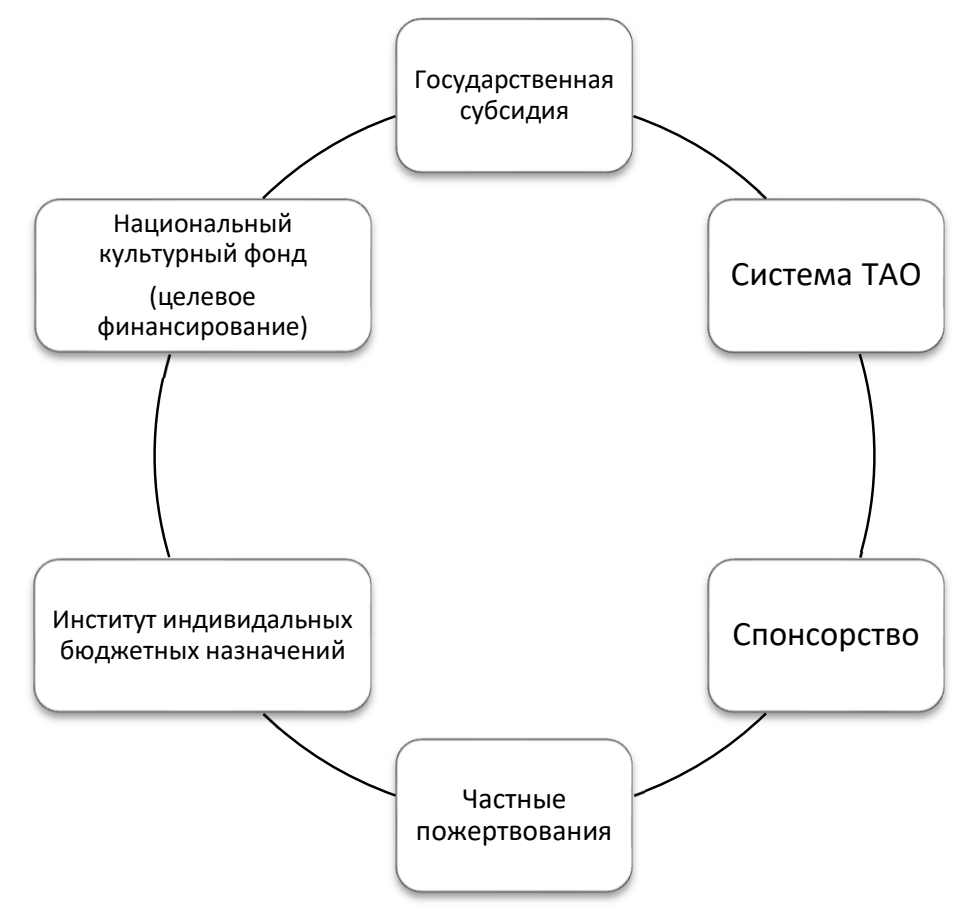

Рис. 5. Институты финансовой поддержки театрального искусства в Венгрии

Государственная финансовая поддержка венгерской театральной системы имеет противоречивый характер. Венгрии - одной из немногих европейский стран - удалось сохранить блок стационарных репертуарных театров - так называемых «каменных театров», что в результате привело к формированию разнообразных проявлений театрального мира, предлагающего зрителю и классическое, и современное искусство. Помимо неоспоримых достижений, связанных с сохранением работающих театральных объектов, в настоящее время страна сталкивается с целым рядом проблем.

Использованные сравнительные примеры характеризуют уровень зарубежных коллег, как более продвинутый, и могут послужить причиной для частичного заимствования венгерского опыта. Нужно учитывать, что повышенный риск бюрократизации, коррупции и информационной изоляции актуален для России так же, как и для Венгрии. То есть, заимствование может быть успешным только с учетом тех ошибок, которые допустили венгерские эксперты при формировании нормативных актов, а также специфики российской общеэкономической и театральной среды. Теоретически в Росси возможно введение механизма, подобного системе ТАО, но на момент существования/развития института бюджетных назначений (то есть не раньше, чем через 7 лет), с глубоким анализом специалистов экономики культуры во избежание проблем переноса института в российские реалии, также специалистов законотворчества 
для качественного подхода к формированию законодательных актов. При грамотной работе по созданию механизма в будущем возможно получение полноценного института государственной косвенной поддержки в России.

\section{Библиография}

ХАУнинА 2013: Хаунина, Е.А., «Процентная филантропия» - проблемы трансплантации успешного института финансовой поддержки культурной деятельности. // Экономика культуры: новый ракурс старых проблем / Отв. ред. А.Я. Рубинштейн, В.Ю. Музычук - Москва: ИЭ РАН.

Ольга РОМАНОВА State Institute of Art

Moscow, Russia

89153095888@mail.ru

Екатерина ХАУнинА

State Institute of Art

Moscow, Russia

haunina@mail.ru 